\title{
Optimalisasi Persiapan Ruang Muat Pada Musim Dingin di MV. JK PIONEER
}

\author{
Dirgantara Kata Ponganan") Dodik Widarbowo') ${ }^{2}$ Aries Allo Layuk ${ }^{3)}$ \\ Politeknik IImu Pelayaran Makassar \\ Jalan Tentara Pelajar No. 173 Makassar, Kode pos. 90172 \\ Telp. (0411) 3616975; Fax (0411) 3628732
}

\begin{abstract}
ABSTRAK
Penelitian ini bertujuan meningkatkan pengetahuan mengenai cara menyiapkan ruang muat dengan baik dan sesuai prosedur. Penelitian ini dilaksanakan di MV. JK Pioneer, yang merupakan salah satu armada kapal milik JK Maritime Inc. Pelaksanaan penelitian selama dua belas bulan, sehingga sumber data diperoleh langsung dari tempat penelitian berupa informasi-informasi berdasarkan hasil pengamatan yang disajikan dalam bentuk deskriptif menggunakan metode kualitatif. Hasil penelitian menunjukkan bahwa masih terdapat banyak kekurangan yang terjadi dalam proses persiapan ruang muat pada musim dingin, baik dalam hal pengetahuan maupun perlengkapan peralatan.
\end{abstract}

Kata Kunci : Optimalisasi, Persiapan Ruang Muat, Musim Dingin.

\section{PENDAHULUAN}

Peran Transportasi Laut di dalam perkembangan suatu negara sangatlah penting. Hal ini berkaitan dengan kapasitas angkutan laut terutama kapal-kapal niaga yang mendistribusikan muatan dalam jumlah besar dengan biaya lebih murah dibandingkan sarana angkutan lain, terutama untuk kegiatan ekspor-impor barang yang dapat menghasilkan devisa bagi negara. Oleh karena itu, sarana angkutan laut untuk pendistribusian barang menjadi alternatif utama.

Dalam dunia pelayaran, cuaca merupakan faktor yang sangat penting, karena cuaca dapat mempengaruhi waktu tempuh dalam berlayar. Ketika kapal menghadapi cuaca buruk maka kapal harus menyesuaikan kecepatan dan mengatur olah gerak yang dapat menyebabkan keterlambatan pada saat tiba di pelabuhan. Begitu pula dengan persiapan ruang muat, cuaca buruk dapat mempengaruhi aktivitas ini. Pada daerah yang beriklim dingin, seperti di negara Korea, China, 
Rusia dan Kanada, seringkali kapal-kapal berhadapan dengan cuaca sangat ekstrim. Salah satunya ialah pembekuan air laut dan pada puncak musim dingin, tidak jarang lautan yang berubah menjadi es dengan suhu dibawah nol derajat celcius.

Demi kelancaran kegiatan persiapan ruang muat, pelaksanaan persiapan ruang muat pada umumnya dilaksanakan oleh awak kapal. Persiapan ruang muat memerlukan perencanaan dan penetapan strategi yang tepat sehingga sebelum kapal tiba di pelabuhan tujuan, ruang muat telah siap untuk dimuati. Tiap kapal harus dapat mengangkut muatan semaksimal mungkin sesuai dengan sarat dan rencana pemuatan yang telah ditentukan. Pada saat kapal akan melakukan pemuatan ternyata bagian dalam palka dilekati es sehingga pada saat surveyor datang ke kapal, menyatakan kapal belum siap untuk dimuati dan akhirnya proses pemuatanpun ditunda dan pihak kapal akan mengalami kerugian waktu dan biaya. Selain itu kita dapat menghindari dan mencegah dampakdampak negatif yang akan terjadi dengan melakukan persiapan-persiapan dan tindakan yang baik dan benar agar proses persiapan ruang muat pada musim dingin berjalan dengan baik, untuk itu kru kapal harus dapat mengambil tindakan yang benar guna mengatasi hal tersebut. Sehubungan dengan latar belakang diatas maka, penulis mengambil judul "Optimalisasi Persiapan Ruang Muat Pada Musim Dingin di MV. Jk Pioneer"

Berdasarkan latar belakang tersebut penulis mengangkat rumusan masalah apa penyebab keterlambatan persiapan ruang muat pada saat musim dingin di MV. JK Pioneer?

\section{TINJAUAN PUSTAKA}

Optimalisasi adalah hasil yang dicapai sesuai dengan keinginan, jadi optimalisasi merupakan pencapaian hasil sesuai harapan secara efektif dan efisien. Menurut Kamus Besar Bahasa Indonesia (Depdibkub 1995:628) optimalisasi berasal dari kata optimal yang berarti terbaik. Pengertian optimalisasi dalam penelitian ini adalah suatu upaya yang 
dilakukan untuk menjadikan proses pengerjaan persiapan ruang muat di atas kapal saat musim dingin dapat terlaksana dengan baik sesuai dengan tujuan yang telah ditetapkan.

Menurut Irawadi (2009) tentang pengertian persiapan, bahwa persiapan adalah suatu kegiatan yang akan dipersiapkan sebelum melakukan kegiatan.

Istopo dan Karlio (1976 : 235-236) menjelaskan bahwa persiapan palka perlu dilakukan dengan beberapa hal antara lain yaitu:

a. Menyapu bersih mulai dari atas ke bawah.

b. Membuka tutup-tutup got dan harus diperiksa.

c. Alat-alat kebakaran atau alat $\mathrm{CO}_{2}$ harus dites.

d. Papan-papan penutup palka di tween deck harus diperiksa kondisinya.

e. Papan-papan penutup tanki dasar berganda (spare ceiling) diperiksa dan ditempatkan yang baik.

f. Pagar-pagar keamanan (guard rail),

g. Dunnage harus disusun sedemikian rupa sesuai kebutuhannya,

Menurut Isbester (2010: 78-85), berpendapat bahwa, selain mempersiapkan ruang muat, maka harus diperiksa pula peralatan yang mendukung dalam proses pemuatan yang dilakukan saat persiapan ruang muat, seperti pengecekan terhadap ventilasi palka, Ballast Vent Pipe, lubang air pada hatch coaming (Drain Hold) dan cargo handling gear serta dalam proses pembersihan palka dikeadaan pembekuan penyiraman menggunakan air panas dan pemanas yang terhubung di pelbuhan.

Dalam pelakasaanaan persiapan ruang muat harus diperhatikan prinsip prinsip pemuatan Adapun 5 prinsip pemuatan yang baik adalah :

1. Melindungi awak kapal dan buruh (Safety of crew and longshoreman)

2. Melindungi kapal (to protect the ship).

3. Melindungi muatan (to protect the cargo).

4. Melakukan muat bongkar secara cepat dan sistematis (rapid 
and systematic loading and discharging).

5. Penggunaan ruang muat semaksimal mungkin.

\section{METODE PENELITIAN}

Dalam penulisan ini, digunakan metode penelitan kualitatif, metode penelitian yang berlandaskan pada filsafat postpositivisme, digunakan untuk meneliti pada kondisi obyek yang alamiah, teknik pengumpulan data dilakukan secara triangulasi (gabungan), analisis data bersifat induktif/kualitatif, dan hasil penelitian kualitatif lebih menekankan makna daripada generalisasi.

Penelitian dilaksanakan pada saat praktek laut selama 1 (satu) tahun di kapal MV. JK PIONEER milik perusahaan pelayaran JK MARITIME. Dengan alamat perusahaan (head office) 5F, Parkview Bldg. 44-5, Banpo-daero 30-gil, Seocho-Gu, Seoul, 06646, Korea.

Namun berdasarkan topik yang diambil, penulis secara spesifik melakukan penelitian pada musim dingin yang berawal dari bulan Desember 2018 di wilayah lautan Korea dan Russia.

Adapun teknik pengumpulan data yang digunakan dalam penelitian ini akan dijelaskan sebagai berikut :

1. Pengumpulan data dengan Observasi (Observation)

2. Pengumpulan data dengan Metode Wawancara (interview)

3. Teknik pengumpulan data dengan Metode Studi Pustaka

\section{HASIL PENELITIAN DAN PEMBAHASAN}

Berdasarkan penelitian di MV. JK Pioneer saat musim dingin, persiapan ruang muat merupakan suatau bagian yang sangat penting sebelum kembali memuat. Oleh karena itu, diperlukan langkah-langkah kerja yang tepat agar ruang muat dapat disiapkan dalam waktu yang cepat dan tepat, utamanya saat musim dingin tiba. Dalam melakukan persiapan ruang muat, yang perlu di perhatikan adalah kebersihan bilges, hatch cover, ventilation da bagian dalam dari ruang muat itu sendiri. Koordinasi dan penerapan prosedur yang baik sesuai dengan perencaan 
yang telah dibuat Mualim I sangatlah penting untuk dipahami dan dikerjakan dengan baik oleh semua kru dek. Akan tetapi, sering terjadi berbagai masalah yang timbul pada saat proses pemuatan tersebut berlangsung. Utamanya saat musim dingin memberi dampak yang sangat signifikan dalam proses persiapan ruang muat sampai pada pemuatan berlangsung. Berikut adalah beberapa kejadian yang terjadi di MV. JK Pioneer selama proses persiapan ruang muat :

\section{Terjadinya kerusakan peralatan}

Pada tanggal 29 Desember 2018, MV. JK Pioneer saat itu berada dalam perjalanan menuju ke Vostochny, Rusia setelah melakukan proses pembongkaran muatan coal di Boryeong, Korea. Dalam perjalanan tersebut ditempuh selama 6 hari. Selama proses perjalanan dilakukan proses persiapan ruang muat yang dilakukan oleh kru dek yang terdiri dari Bosun, $3 \mathrm{AB}$, OS, Deck Cadet dan dibawah pengawasan Mualim I. Proses ini berlangsung lambat dikarenakan kurangnya awak kapal ditambah dinginnya suhu di dalam ruang muat dan air laut yang digunakan juga demikian sehingga menyulitkan pencucian ruang muat. Ini disebabkan karena bulan Desember adalah waktu dimana daerah lintang tinggi memasuki musim dingin. Hal tersebut semakin dipersulit dengan rusaknya beberapa peralatan untuk pembersihan ruang muat. Dimulai dari pompa bilges yang tidak berjalan dengan baik. Oleh karena itu, proses pembersihan muatan sisa di dalam lubang bilges menjadi terhambat. Hal tersebut kemudian coba diselesaikan dengan menggunakan welding pump. Namun, hal tersebut kembali menemui kendala setelah angin kompresor tidak dapat mampu menggerakkan welding pump. Dan juga selang yang akan digunakan menjadi kaku karena pengaruh musim dingin yang yang ekstrim. Akhirnya, Mualim I memutuskan untuk melakukan proses pembersihan bilges secara manual. Sehingga waktu untuk membersihkan satu palka menjadi sangat lama. Selama kapal berlayar, angin bertiup kencang 
dan ombak yang cukup tinggi. sehingga. Hasilnya yang semula direncanakan 2 hari selesai akhirnya menjadi 6 hari. Saat kapal tiba di Vostochny dan berlabuh jangkar, Mualim I melakukan pemeriksaan di atas dek dan ruang muat berhubung saat itu cuaca sudah cukup baik. Pada saat pemeriksaan Mualim I menemukan tumpukan salju di dek dan es yang keras di hatch coming yang dapat membuat hatch cover sulit untuk di buka saat pemuatan. Melihat kondisi tersebut, Mualim I langsung memanggil semua kru dek untuk menghancurkan es yang menempel pada hatch coming. Proses pembersihan kembali memakan waktu yang lama karena menggunakan peralatan manual dan es yang sangat keras. Setelah sandar dipelabuhan untuk melakukan proses pemuatan, pihak agent dan surveyor melakukan pengecekan pada kondisi ruang muat. Dan hasilnya ditemukan masih adanya genangan air di palka nomor 4 yang membuat tutup bilges terlepas.

Gambar 4.1. Tumpukan salju dan es saat pemuatan

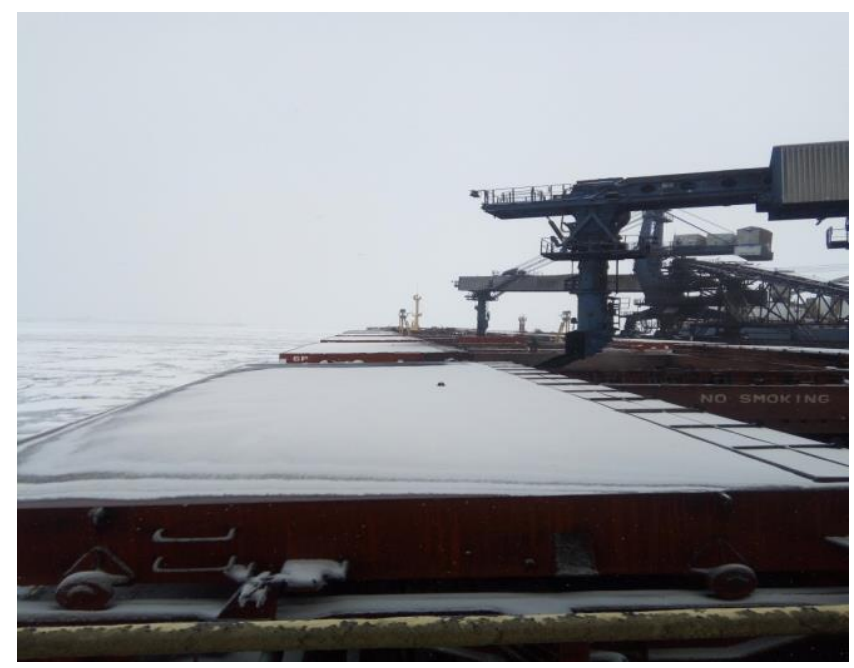

Sumber : MV. JK Pioneer : 2019

2. Terjadinya keterlambatan dalam persiapan ruang muat

Pada tanggal 29 Januari 2019, kapal telah selesai melakukan proses bongkar di Donghae, Gangwondo, Korea dan menuju ke Vanino, Rusia. Perjalanan menuju Vanino begitu singkat hanya 3 hari saja, sehingga persiapan ruang muat harus diselesaikan secepatnya. 
Keadaan cuaca saat masih di wiliayah perairan Korea sekitar $-10^{\circ}$ Celcius dan saat memasuki wilayah perairan Rusia berada diangka sekitar $-18^{\circ}$ Celcius. Hal tersebut wajar karena bulan Januari hingga Februari merupakan puncak dari musim dingin. Salju turun begitu deras, angin bertiup kencang sehingga saat pembersihan ruang muat ventilasi ditutup rapat, hacth cover ditutup, dan hanya man hole yang dibuka sebagai sirkulasi udara. Namun, sebelum hatch cover ditutup terlebih dahulu di masukan heater dan dan lampu untuk pencahayaan. Selama proses persiapan ruang muat beberapa kali harus terhenti dikarenakan air begitu dingin dan sangat cepat membuat badan menjadi kaku. Karena hal tersebut, Mualim I berdiskusi dengan Nahkoda untuk berkoordinasi agar proses persiapan ruang muat di bantu oleh semua kru. Karena singkatnya waktu perjalanan dan cuaca yang sangat ekstrem membuat persiapan ruang muat tidak dapat bila hanya di lakukan oleh kru dek. Setelah koordinasi dilakukan, setelah makan siang semua semua kru terlibat termasuk Nahkoda dan KKM, terkecuali yang jaga dikarenakan posisi kapal sedang berlayar. Sebelum melaksanakan proses persiapan ruang muat, Mualim I melakukan technical meeting tentang proses kerja yang akan dilakukan. Pekerjaan dengan cepat di mulai dengan arahan dibawah komando Mualim I. Namun dalam pelaksaannya ada beberapa koordinasi yang tidak berjalan dengan baik utamanya dari kru mesin yang tidak familiar dengan pekerjaan di dek. Masalah lain pun muncul saat dalam pengawasan, Nahkoda dan KKM tidak bertahan lama dalam pengawasan kerja sehingga hanya Mualim I yang harus bolak balik mengecek sehingga ada beberapa hal yang terlupakan. Satu persatu palka dari nomor 1 sampai 7 dikerjakan di bawah cuaca yang ekstrim dengan salju yang senantiasa turun. Pekerjaan pun selesai dalam 5 hari walaupun dengan bantuan semua kru yang ada. Tetap terjadi keterlambatan dari target yaitu 3 hari karena waktu yang sangat sempit, kurang koordinasi pembagian tugas dan kurangnya 
pengawasan yang di lakukan.

Gambar 4.2. Lautan menjadi es

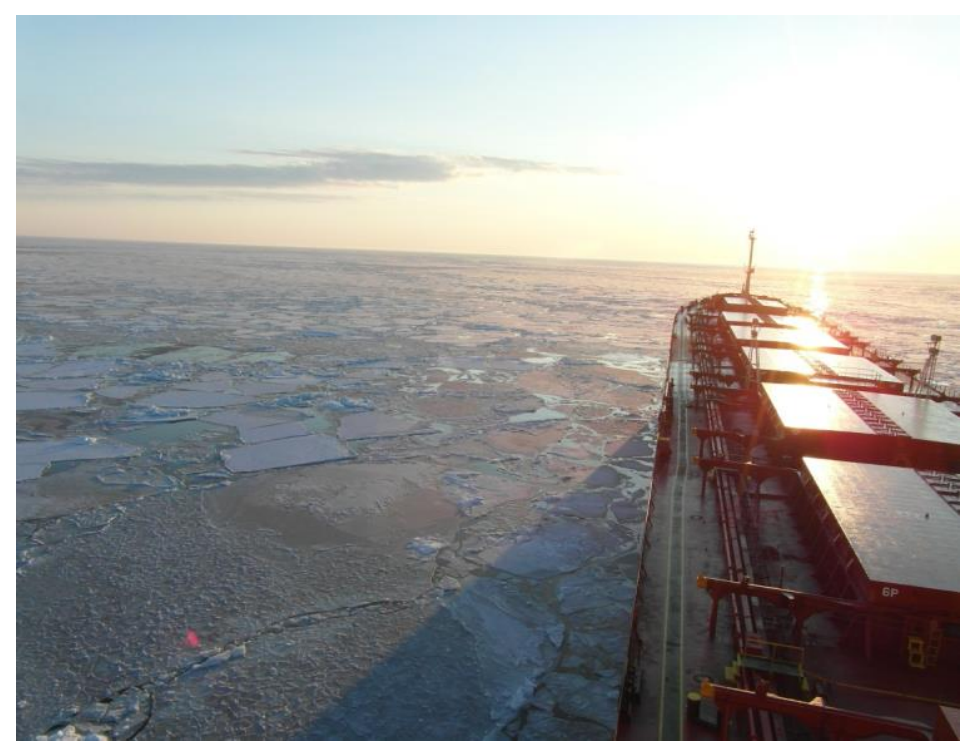

Sumber : MV. JK Pioneer : 2019

Selama proses persiapan ruang muat di MV. JK Pioneer, peneliti mengamati beberapa hal yang menjadi sangat penting dalam proses persiapan ini. Hal tersebut adalah perlengkapan dan peralatan khusus yang digunakan oleh kru dek dalam melaksanakan pekerjaan. Berikut adalah perlengkapan dan peralatan tersebut :

a. Pelengkapan kru :

1) Helm

2) Skullcaps

3) Ear plug

4) Winter suit

5) Winter boat

6) Winter gloves

7) Safety glasses

8) Ear muff

b. Peralatan kru :

1) Heater

2) Cargo Light

3) Portable Crane 
4) Hose

5) Nozzle

6) Burlap

7) Scrap

8) Crowbar

9) Bucket

10) Shovel

11) Broom

Dari kejadian diatas dapat diketahui bahwa ada beberapa hal yang menjadi kendala dalam proses persiapan ruang muat di MV. JK Pioneer saat musim dingin. Hal tersebut antara lain :

1. Terjadinya kerusakan peralatan

Berikut merupakan beberapa hal yang menyebabkan terjadinya kerusakan peralatan persiapan ruang muat :

a. Peralatan tidak dirawat dengan baik

Dalam melakukan proses pembersihan ruang muat para awak kapal menggunakan alat-alat penunjang kebersihan ruang muat seperti : sapu, sikat, pel, rugs, dan masih banyak lagi alat-alat penunjang kebersihan ruang muat yang lainnya yang digunakan oleh awak kapal dalam proses pembersihan ruang muat. Setelah selesai mengunakan alat-alat penunjang kebersihan ruang muat tersebut, para awak kapal hanya meletakkan peralatan tersebut begitu saja tanpa diposisikan dan di tata supaya rapi dan tidak rusak. Kurangnya kesadaran awak kapal untuk menjaga dan merawat peralatan kebersihan ruang muat tersebut menyebabkan peralatan kebersihan ruang muat menjadi rusak dan tidak layak lagi digunakan dalam proses pembersihan ruang muat, sehingga mengakibatkan proses pembersihan ruang muat membutuhkan waktu yang lama karena peralatan yang sudah rusak dan tidak layak lagi untuk digunakan. 
C. Peralatan tidak di cek

Peralatan penunjang kebersihan ruang muat yang selanjutnya adalah pompa yang terdapat pada got di dalam ruang muat yang berfungsi untuk memompa air keluar dari dalam ruang muat setelah ruang muat selesai dibilas dengan menggunakan air. Karena letaknya yang sulit untuk dijangkau maka pompa tersebut sering diabaikan oleh para awak kapal untuk dilakukan pengecekan, seharusnya sebelum melakukan proses pembilasan ruang muat pompa tersebut dicek terlebih dahulu sehingga dapat bekerja secara maksimal dalam memompa air keluar dari ruang muat. Pernah peneliti alami di atas kapal pada saat ruang muat selesai dibilas pompa tersebut macet dan tidak bisa digunakan untuk memompa air keluar dari ruang muat, sehingga para awak kapal harus mengeluarkan air dari dalam ruang muat secara manual dengan menggunakan ember yang diikat dengan menggunakan tali dan kemudian air dibuang keluar dari dalam ruang muat dengan menggunakan ember tersebut sedangkan awak kapal yang lain sedang memperbaiki pompa, sehingga dengan adanya kejadian tersebut proses pembersihan ruang muat membutuhkan waktu yang sangat lama, ditambah situasi musim dingin yang membuat proses tersebut semakin berjalan lambat dan hati-hati. Sehingga proses persiapan ruang muat semakin terlambat.

2. Terjadinya keterlambatan dalam persiapan ruang muat

Berikut merupakan beberapa hal yang menyebabkan terjadinya keterlambatan dalam persiapan ruang muat :

a. Kurangnya waktu yang tersedia

Proses pembersihan ruang muat diatas kapal melibatkan seluruh awak kapal. Pihak kapal yang berwenang adalah Mualim I sebagai penanggungjawab dalam kebersihan ruang muat dibawah wewenang Nakhoda, selanjutnya Bosun yang 
bertanggung jawab atas semua awak kapal yang melakukan proses pembersihan ruang muat. Dan proses pembersihan ruang muat tidak sesuai dengan prosedur yang ada. Dikarenakan kapal MV. JK Pioneer mempunyai banyak ruang muat dan seluruh ruang muat tersebut harus bersih untuk menerima muatan selanjutnya sedangkan waktu yang tersedia sangat pas bahkan kurang untuk menyelesaikan proses pembersihan semua ruang muat yang ada di kapal, karena apabila masih ditemukan sisa kotoran dari muatan sebelumnya maka dari pihak cargo surveyor tidak akan memberi izin kepada pihak kapal untuk melakukan proses pemuatan. Apalagi dengan kondisi musim dingin yang membuat es dengan mudah terbentuk dalam ruang muat dan akan menjadi bahan pertimbangan bagi surveyor dalam memberi ijin pemuatan dilakukan.

b. Kurangnya koordinasi dalam pembagian tugas

Salah satu penyebab terlambatnya proses persiapan ruang di MV. JK Pioneer adalah kurangnya koordinasi dalam pembagian tugas, sehingga awak kapal tidak mempunyai target dan tujuan ruang muat yang manakah yang harus diselesaikan terlebih dahulu dalam proses pembersihan ruang muat, sehingga para awak kapal bekerja dalam proses pembersihan ruang muat dengan kacau dan tidak terkoordinasi dengan baik. Sehingga dengan adanya kejadian tersebut, proses persiapan dalam ruang muat pada kapal tidak maksimal dan masih meninggalkan sisa muatan sebelumnya. Kejadian ini pernah dialami oleh kapal MV. JK Pioneer saat kapal berada di Rusia. Pada saat kapal telah mendapatkan jadwal untuk sandar dan melakukan pemuatan, akan tetapi proses pembersihan belum selesai karena cuaca yang ekstrim sehingga tidak banyak aktivitas yang dapat dilakukan di dek. Ditambah waktu yang diberikan oleh agen sangat sempit sehingga pembersihan tidak optimal 
d. Kurangnya pengawasan

Dalam proses pembersihan ruang muat, Mualim I selaku perwira yang bertanggung jawab terhadap proses pembersihan ruang muat di bawah Nakhoda masih sangat kurang karena tidak ada pengecekan yang dilakukan oleh Mualim I dan tidak ada juga bimbingan serta arahan atau instruksi yang diberikan oleh Mualim I kepada Bosun atau awak kapal dalam proses pembersihan ruang muat, sehingga awak kapal dengan sembarangan dalam bekerja membersihkan ruang muat, para awak kapal melakukan pembersihan ruang muat tidak sesuai dengan prosedur dan tidak maksimal dalam melakukan pembersihan ruang muat. Para awak kapal yang melakukan pembersihan ruang muat hanya membersihkan ruang muat dengan cara dibilas dengan menggunakan air laut yang disalurkan melalui hoze dari fire hydrant dengan tanpa menggunakan chemical soap dan tanpa melakukan proses brush dengan menggunakan alat-alat penunjang kebersihan ruang muat. Setelah selesai melakukan proses pembilasan terhadap dinding dan lantai pada ruang muat para awak kapal pun tidak melakukan proses pengeringan terhadap ruang muat. Akibatnya masih terdapat sisa-sisa air yang dapat membentuk es karena kapal berada di daerah dingin dengan puncak musim dingin yang ekstrim sehingga sangat mudah dalam proses terbentuknya es. Sehingga pada saat cargo surveyor melakukan pengecekan terhadap ruang muat, cargo surveyor menyatakan bahwa ruang muat belum siap untuk menerima muatan dan cargo surveyor tidak akan menandatangani proses memuat muatan selama masih ditemukan sisa-sisa kotoran yang masih terdapat di dalam ruang muat. 


\section{Pemecahan Masalah}

Dari pembahasan hasil penelitian di atas, ada beberapa cara untuk membantu memecahkan masalah yang telah dirumuskan dalam penelitian, khususnya pada saat proses persiapan ruang muat diatas kapal MV. JK Pioneer pada saat musim dingin. Beberapa hal yang akan dibahas adalah sebagai berikut :

1. Terjadinya kerusakan peralatan

Untuk menjaga peralatan penunjang kebersihan ruang muat tetap dalam kondisi yang bagus dan siap untuk digunakan dalam proses kebersihan ruang muat di kapal agar persiapan kebersihan ruang muat di kapal MV. JK Pioneer dapat berjalan lancar tidak menemui kendala dan selesai tepat waktu sehingga tidak menghambat proses pemuatan di kapal, dapat melakukan hal-hal sebagai berikut :

a. Menjaga dan merawat peralatan dengan baik

Salah satu cara untuk mengoptimalkan proses pembersihan ruang muat adalah dengan menggunakan peralatan yang layak pakai untuk mendukung proses kebersihan ruang muat.

Setelah semua awak kapal selesai menggunakan peralatan penunjang kebersihan ruang muat hendaknya dengan penuh kesadaran dan tanggung jawab awak kapal mengembalikan semua peralatan penunjang kebersihan ruang muat pada tempat yang telah disediakan dan ditata dengan rapi sehingga besok apabila akan digunakan kembali untuk membersihkan ruang muat peralatan tersebut dalam kondisi yang siap pakai dan tidak kuarang jumlahnya, setelah peralatan di tata dengan rapih Bosun mengecek peralatan tersebut dan melakukan pendataan peralatan yang sudah rusak dan tidak layak pakai lagi untuk diberikan kepada Mualim I yang bertanggungjawab membuat laporan shipping order. Mualim I membuat suatu permintaan atau ship order kepada perusahaan pelayaran atas izin dari 
Nahkoda dan Kepala Kamar Mesin dalam hal pengadaan peralatan penunjang kebersihan ruang muat yang sudah rusak dan tidak layak pakai serta spare part yang rusak dan sudah tidak bisa diperbaiki lagi. Pihak perusahaan pun harus mengetahui apa saja yang dibutuhkan oleh setiap armadaarmada kapal yang mereka miliki. Ketika melakukaninspeksi di kapal pihak perusahaan harus benar-benar memperhatikan kekurangan-kekurangan pada kapal tersebut, seperti kurangnya alat alat kebersihan ruang muat (sapu, brush, chemical soap, dan anti coorosive).

Dan selanjutnya perusahaan harus melengkapi kekurangankekurangan tersebut sesegera mungkin agar semua hal yang berkaitan dengan operasi kapal dapat berjalan dengan lancar. Hal ini harus diimbangi oleh awak kapal penerapannya yang sesuai dengan prosedur agar proses pembersihan ruang muat di atas kapal berjalan maksimal terkhusus saat musim dingin.

b. Meningkatkan kesadaran awak kapal untuk merawat peralatan kebersihan ruang muat

Salah satu cara untuk mengoptimalkan proses pembersihan ruang muat adalah dengan cara meningkatkan kesadaran awak kapal untuk merawat peralatan kebersihan ruang muat dengan cara mengumpulkan awak kapal di crew mess pada saat waktu luang atau pada hari libur dan menerangkan lewat media slide (power point) tentang pentingnya merawat alat-alat penunjang kebersihan ruang muat dan proses pembersihan ruang muat yang baik, benar dan sesuai dengan prosedur serta penggunan alat-alat penunjang proses kebersihan ruang muat yang digunakan dalam proses pembersihan ruang muat.

Pentingnya pemberian sosialisasi dan pembelajaran mengenai pembersihan ruang muat dan prosedur yang baik, adalah agar awak kapal dalam melaksanakan pembersihan 
ruang muat dapat sesuai dengan prosedur dan hasil yang didapatkan dapat maksimal dan awak kapal mempunyai pengetahuan tentang bagaimana cara menggunakan peralatan penunjang kebersihan ruang muat dan pentingnya para awak kapal untuk menjaga dan merawat alat-alat penunjang kebersihan ruang muat.

Mualim I dapat memberikan wawasan kepada awak kapal dan memberi pengarahan bahwa alat-alat penunjang kebersihan di atas kapal harus dijaga dan dirawat dengan baik guna mendukung proses pembersihan ruang muat, serta Mualim I memberi contoh yang baik kepada awak kapal untuk menjaga peralatan penunjang kebersihan ruang muat, sehinggaperalatan yang digunakan untukmendukung proses kebersihan ruang muat tetap terawat dan siap untk digunakan keesokan harinya pada saat melakukan proses pembersihan ruang muat lagi dan proses pemuatan tidak akan terhambat lagi dikarenakan ruang muat yang masih kotor dan belum siap untuk menerima muatan.

2. Terjadinya keterlambatan dalam persiapan ruang muat

Untuk menanggulangi terjadinya keterlambatan proses pemuatan di kapal MV. JK Pioneer, maka dapat dilakukan hal-hal sebagai berikut :

a. Mengadakan rapat sebelum pembersihan ruang muat

Salah satu cara untuk memaksimalkan waktu yang tersedia untuk melakukan proses pembersihan ruang muat adalah dengan cara mengadakan rapat sebelum dan sesudah melakukan proses pembersihan ruang muat.

Tujuan dari mengadakan rapat adalah agar dapat mengevaluasi hasil kerja awak kapal yang tidak sesuai dengan prosedur pembersihan ruang muat sehingga awak kapal dapat lebih mengerti akan tugas dan tanggung jawabnya dalam melaksanakan pembersihan ruang muat di atas kapal. Sehingga 
proses pembersihan ruang muat dapat berjalan sesuai dengan prosedur dan pembersihan ruang muat dapat selesai tepat waktu dan tidak mengganggu proses pemuatan sehingga proses pemuatan dapat berjalan dengan lancar.

e. Membuat daftar awak kapal dan bagian ruang muat yang dibersihkan

Salah satu cara untuk mengoptimalkan proses pembersihan ruang muat adalah dengan cara membuat daftar awak kapal dan bagian ruang muat yang dibersihkan dengan cara memberikan sosialisasi kepada awak kapal dengan mengumpulkan awak kapal di crew mess dan menerangkan lewat media slide(power point) proses pembersihan ruang muat yang baik, benar dan sesuai dengan prosedur dan alat-alat yang digunakan dalam proses pembersihan ruang muat serta dilengkapi dengan daftar nama awak kapal dan bagian ruang muat yang harus dibersihkan. Pentingnya pemberian sosialisasi dan pembelajaran mengenai pembersihan ruang muat dan prosedur yang baik, adalah agar awak kapal dalam melaksanakan pembersihan ruang muat dapat sesuai dengan prosedur dan hasil yang didapatkan dapat maksimal.

c. Mengadakan pengawasan

Dalam proses pembersihan ruang muat, Mualim I selaku perwira yang bertanggung jawab terhadap proses pembersihan ruang muat dibawah Nakhoda harus selalu melakukan pengawasan dan pengecekan terhadap awak kapal yang sedang melakukan proses kebersihan ruang muat jika di perlukan Mualim I dapat turun langsung membantu proses pembersihan ruang muat. Mualim I dapat memberikan bimbingan serta arahan atau instruksi kepada awak kapal yang sedang melakukan proses pembersihan ruang muat, sehingga akan berdampak juga pada psikologis para awak kapal bahwa Mualim I ikut turun dalam proses pembersihan 
ruang muat dan membakar semangat awak kapal untuk bekerja membersihkan ruang muat sesuai dengan prosedur dan melakukan pembersihan ruang muat dengan maksimal. Sehingga proses pemuatan tidak akan tertunda lagi dikarenakan oleh ruang muat yang masih kotor dan dapat meminimalisir waktu dan biaya yang dilakukan untuk operasional dalam pembersihan ruang muat.

d. Penerapan prosedur persiapan yang baik

Seluruh kegiatan persiapan ruang muat dalam menghadapi musim dingin dapat dirancang dengan baik dan lebih terorganisir sehingga dapat mengatasi dan mencegah terjadinya hal-hal buruk di atas kapal. Prosedur tersebut sudah seharusnya diimplementasikan oleh seluruh awak kapal untuk menghindari terjadinya masalah yang sering timbul pada saat musim dingin. Namun, hal itu juga harus diimbangi dengan pengalamanpengalaman yang sesuai dengan bidangnya yang dimiliki oleh seluruh kru kapal agar prosedur tersebut dapat diaplikasikan di atas kapal dengan baik. Prosedur tersebut juga harus senantiasa rutin dilaksanakan agar semua awak kapal paham dan dapat bekerja sesuai prosedur.

Berikut ini adalah prosedur persiapan dan pembersihan ruang muat yang baik dan benar :

1) Pembersihan ruang muat dengan cara disapu

Pembersihan ruang muat dengan cara disapu bertujuan untuk mengumpulkan sisa muatan agar bisa diangkat keluar dari ruang muat, sehingga nanti bila dicuci dengan air laut sisa muatan tersebut tidak larut dalam bilges yang dapat membuat pompa dan pipa-pipa alirannya tersumbat. Pada bagian dinding palka yang tinggi, para dek kru menggunakan tongkat panjang yang ujungnyaa dipasangkan scraper atau sapu untuk menjangkau bagian dinding palka masih terdapat sisa muatan. 
2) Pencucian ruang muat dengan air laut

Setelah sisa muatan pada ruang muat telah disapu bersih, kemudian ruang muat dicuci dengan menggunkan air laut. Cara penyemprotan memakai selang karet yang dihubungkan melalui fire hydrant yang ada di bawah ruang muat. Hal ini dilakukan agar mendapatkan semprotan air yang bertekanan tinggi. Pencucian ruang muat dengan air laut bertekanan tinggi ini bertujuan agar ruang muat dapat dibersihkan dengan maksimal hingga mencapai bagian paling atas dari ruang muat maupun sekat-sekat dari frame kapal. Pencucian dilakukan menggunakan air laut karena memerlukan banyak air dan harus bertekanan sangat tinggi agar dapat mencapai bagian paling tinggi dan tersembunyi serta tekanan air yangbeesar tersebut dapat menjatuhkan sisa-sia muatan yang masih terdapat di dalam ruang muatan.

3) Pencucian ruang muat dengan air tawar

Pencucian dengan air tawar dimaksudkan agar ruang muat tidak berkarat setelah dicuci dengan air laut. Pencucian ruang muat dengan air tawar ini juga menggunakan selang karet yang disambungkan dengan fire hydrant yang sebelumnya aliran airnya telah diganti oleh Masinis di engine room dari sea water ke fresh water. Pencucian ruang muat dengan air tawar ini tidak dapat menjangkau seluruh abagian ruang muat bila hanya disiram dari bawah karena tekanannya tidak terlalu kuat, maka penyiraman dari atas ruang muat juga dilakukan mulai dari mutu palka, lubang-lubang ventilasi, rongga muat menggunakan high pressure water jet. Apabila ruag muat berbau, air cucian diberi campuran bahan kimia untuk menghlangkan baunya. 


\section{4) Pembersihan Bilges}

Pembersihan ini biasanya dilakukan perkelompok yang tiap kelompoknya terdirlah dari 3 (tiga) orang salah satu dari mereka masuk kedalam got palka, Kemudian sampah-sampah sisa muatan di dalam got yang tidak dapat dihisap oleh pompa got segera diangkat keluar agar tidak tidak merusak pompa got. Kemudian sisa-sisa air yang ada di dalam got juga segera dihisap oleh pompa sampai batas pompa tidak bisa lagi menghisapnya. Setelah pembersihan bilges selesai, tutup saringan (strainer) dilapisi dengan karung goni atau burlap untuk mencegah muatan sekecil apapun yang jatuh kedalam got palka.

\section{PENUTUP}

\section{A. Simpulan}

1. Peralatan persiapan ruang muat banyak tidak mendukung dan dalam kondisi yang kurang layak. Hal tersebut dipersulit dengan kondisi musim dingin yang membuat beberapa peralatan menjadi tidak optimal dalam penggunaannya. Perawatan berkala dan pemeliharaan khusus untuk menghadapi musim dingin juga sangat diperlukan. Dan jika perlu Mualim I mengadakan shipping order kepada perusahaan untuk memaksimalkan proses kerja persiapan ruang muat saat musim dingin.

2. Waktu yang tersedia juga sangat sedikit ditambah jumlah awak kapal yang terbatas serta kondisi musim dingin membuat pekerjaan menjadi semakin melambat. Dan juga pengawasan yang masih kurang sehingga awak kapal tidak bekerja dengan sungguh-sungguh.

B. Saran

1. Sebaiknya Mualim I dan Bosun serta seluruh awak dek mempersiapkan dengan baik semua peralatan yang akan digunakan serta memastikan dapat berfungsi dengan baik. Dan jika ditemukan kerusakan segera diperbaiki atau di adakan pembaharuan peralatan. Serta diharapkan perusahaan dapat 
merespon dengan cepat kebutuhan kapal. Utamanya saat kapal menghadapi musim dingin, dimana peralatan membutuhkan perawatan khusus agar dapat beroperasi dengan maksimal saat digunakan.

2. Sebaiknya Mualim I sering mengadakan edukasi pada awak kapal untuk membuat persiapan ruang muat lebih efisien waktu. Dan juga memberi motivasi untuk bekerja lebih baik. Pengawasan juga sangat dibutuhkan untuk membuat persiapan ruang muat tepat waktu. Mengingat persiapan dilakukan saat musim dingin jadi benar-benar memperhatikan manajemen waktu yang baik.

\section{DAFTAR PUSTAKA}

[1]. Arso Martopo dan Herry Gianto.( 1990). Pengoperasian Pelabuhan Laut. Jakarta . Trijaya.

[2].BIMCO. (2005). Ice Hand Book Series. Bagsvaerd. Baltic Informatique.

[3]. Donn, William L.(1975). Meteorology. New York . McGraw-Hill.

[4]. House D. J. (1994). Seamanship Techniques Single Volume Edition, USA . Butterworth-Heinemann Ltd.

[5]. Istopo dan Karlio O.S. (1976) Kapal dan Muatannya. Jakarta . Trijaya.

[6]. J. Isbester.(2010). Bulk Carrier Practice 2nd Edition. The Nautical Institute.

[7]. John M. Downard. (1981). Managing Ships ( Ship Management Series). USA . Fairplay Publication.

[8]. Karl J. Thompson.(1983). Meteorology for Mariners. UK . Her Majesty Books.

[9]. Sugiyono.(2014).Metode Penelitian Kuantitatif, Kualitatif dan R\&D Cetakan Ke-21. Bandung. Penerbit Alfabeta.

[10]. Thomas R.E. (1983). The Properties and Stowage of Cargoes, England. Ferguson Brown and Son.

[11]. Anggasvara. (2014). https.//brainly.co.id/tugas/945324 